\title{
The Marcus Kolb Site (41CE438), Cherokee County, Texas, Part 2
}

Timothy K. Perttula

Heritage Research Center, Stephen F. Austin State University

Follow this and additional works at: https://scholarworks.sfasu.edu/ita

Part of the American Material Culture Commons, Archaeological Anthropology Commons, Environmental Studies Commons, Other American Studies Commons, Other Arts and Humanities Commons, Other History of Art, Architecture, and Archaeology Commons, and the United States History Commons

Tell us how this article helped you.

This Article is brought to you for free and open access by the Center for Regional Heritage Research at SFA ScholarWorks. It has been accepted for inclusion in Index of Texas Archaeology: Open Access Gray Literature from the Lone Star State by an authorized editor of SFA ScholarWorks. For more information, please contact cdsscholarworks@sfasu.edu. 


\section{The Marcus Kolb Site (41CE438), Cherokee County, Texas, Part 2 \\ Creative Commons License \\ (c) $($ ) $(9)$}

This work is licensed under a Creative Commons Attribution-NonCommercial 4.0 International License 


\title{
The Marcus Kolb Site (41CE438), Cherokee County, Texas, Part 2
}

\author{
Timothy K. Perttula
}

\section{INTRODUCTION}

The Marcus Kolb site is an early to mid-19th century occupation on an upland ridge adjacent to an intermittent tributary of Gum Creek in the upper Neches River basin in East Texas (Perttula 2011:1-11). The recovcred artifacts from the site, especially black transfer-printed pearlware sherds, a worked stoneware sherd, and possibly a cut and crimped copper-based artifact, suggested that the site could have been occupied as early as the 1820 s-early 1830 s, during the time when this part of East Texas was occupied by the Cherokee. The tantalizing possibility of a Cherokee Indian occupation is negated to some extent by the chronological evidence that can be drawn from the decorated whiteware sherds from the site (Perttula 2011:3-4 and Figure 2), as the preponderance of that evidence is more consistent with a ca. 1840-1860 occupation, one that postdated the Cherokee occupation of East Texas. That would mean that the historic occupation of the Marcus Kolb site is most likely the product of an Anglo-American settlement.

Subsequent to the analysis of the Marcus Kolb artifacts described above, additional historic artifacts from the site were provided for study by the Kolb family. These artifacts came from surface collections on the slope south and southwest of a test unit near what was described as a "House Site Area." The location of this area relative to the other identified archaeological deposits at the site (Perttula 2011:1) is not known. The size of the test unit is also not known, but its coordinates (N6-8 and E1-4 as well as W3) suggests it may have been $3 \times 7 \mathrm{ft}$. No depth measurements were specified for the test unit excavations.

\section{ADDITIONAL ARTIFACTS}

The new artifact collection from the Marcus Kolb site, has 72 ceramic, glass, and metal artifacts (Table 1), not including a modern shotgun shell (Winchester No. 12 Repeater, W.R.A. New No. 4 Co.) from a surface collection. The most common kind of artifact in the collection are cut nails (1820-1891, see Wells 2000) and nail shanks, which together comprise $35.6 \%$ of the collection. Their presence in the collection indicates that wood-framed structure was built at or near the test unit location sometime in the early to late 19th century. More than $21.9 \%$ of this Marcus Kolb collection includes refined earthenware sherds, among them plain whiteware, plain ironstone (post-1850), and post-1840s blue annular ware with blue, black, and white bands (Majewski and O'Brien 1987:163). The four-holed porcelain button was a common clothing button on sites dating after the 1850s (Meissner 1997). There is no pre-1830s pearlware in this collection, while in the earlier ceramic assemblage from the site $30 \%$ of the sherds were pearlware (Pcrttula 2011:3).

The stoneware sherds found in the archaeological deposits at the Marcus Kolb site include alkalineglazed sherds $(n=2)$, salt-glazed sherds $(n=1)$, and yellow ware $(n=1)$ (see Table 1). These particular kinds of stoneware would have been manufactured and used between the 1830s and ca. 1875. Salt glazing was one of the more commonly employed glazes in the manufacture of utilitarian stoneware (Greer 1981:180). The absence of salt-glazed stoneware sherds with a natural clay slipped interior surface suggests that these particular sherds are from stoneware vessels that were made before cad, 1870 (Lebo 1987:140). Alkaline-glazed stoneware sherds were produced in the 1850s and 1860s in East Texas kilns (Leho 1987). 
Table 1. Additional artifacts from the Marcus Kolb site.

\begin{tabular}{llr}
\hline Artifact category & No. & Percer \\
\hline Refined Earthenware Sherds & & \\
Plain whiteware & & 12.3 \\
Blue annular ware & 9 & 4.1 \\
Plain Ironstone & 3 & 4.1 \\
Porcelain 4-hole button & 3 & 1.4
\end{tabular}

\section{Stoneware Sherds}

Alkaline-glazed

Salt-glazed

Unidentified

1.4

Yellowware

2.7

2.7

\section{Bottle Glass}

amber

aqua (paneled)

brown

2

12.3

.1

1.4

clear

ercentage

3

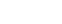

Window Glass

aqua-colored, $2.1 \mathrm{~mm}$ thick

1

1.4

Nails

cut nail

unidentified shank

22

30.1

4

5.5

\section{Metal}

fork, cupreous

cast iron fragment

button

iron nut

iron file

iron tool fragment

harmonica plate

crushed canister or cup

horseshoe fragment

$\begin{array}{ll}1 & 1.4 \\ 1 & 1.4 \\ 1 & 1.4 \\ 1 & 1.4 \\ 1 & 1.4 \\ 1 & 1.4 \\ 1 & 1.4 \\ 1 & 1.4 \\ 1 & 1.4\end{array}$

1.4

9.6

1.4

6.9

Total

100.0 
Yellowware began to produced in the $1820 \mathrm{~s}$ in England, but by the $1840 \mathrm{~s}$ it was also being manufactured in the United States, especially in the Midwest (Leibowitz 1985:4). The peak production of yellow-

ware vessels was in the 1860 s and 1870 s, although it was still being made in the early 1900 s (Leibowitz 1985:14).

The bottle glass from the Marcus Kolb site are from hand-blown bottles of several different colors, including aqua (including a sherd from a paneled bottle), clear, and brown (see Table 1), as well as amber (possibly a later 20th century introduction to the archaeological deposit). These vessels or containers would have held medicinal liquids and liquor (heer and wine). There are no bottle lips or cmbossed lettering on the sherds, limiting any specific determination of their age.

A single piece of aqua-colored window glass is in the collection, suggesting that the likely woodframed huilding in the investigated area at the Marcus Kolb site also had a window. The thickness of the window glass is $2.1 \mathrm{~mm}$, which according to Moir's (1987) window thickness regression is indicative of a pane of window glass that would have been manufactured around $1889 \pm 7$.

The metal artifacts found in this collection at the Marcus Kolb site represent a diverse assortment of horse gear, tools, cutlery, clothing, and part of a musical instrument (sec Table 1). Mure specifically they range from horse parts to buttons, the handle of a cupreous-based fork fragment, cast iron fragments, and a plain metal clothing button.

\section{CONCLUSIONS}

The analysis of the 2nd batch of artifacts from the Marcus Kolb site (41CE438) is from an area thnught to mark the location of an historic house site. The prevalence of cut nails apparently confirms that the artifacts are from the occupation of a wood-framed house, but the known date of cut nail manufacture (1820-1891) provides only a very general 19 th century time frame. The refined earthenwares, stonewares, and the one porcelain button in this batch of artifacts suggest that the historic occupation in the house arca postdates the 1840 s, and may have lasted until ca. 1870 . The one piece of window glass suggests some use of the sitc area in the 1880s. Given the estimated age of the historic occupation in the house area at the Marcus Kolb site, it is reasonable to conclude that the historic occupation of the site is most likely the product of an Anglo-American farm settlement.

\section{REFERENCES CITED}

Greer, G. H.

1981 American Stoneware: The Art and Craft of Utilitarian Pottery. Schiffer Publishing Ltd., Exton, Pennsylvania.

Lebo, S. A.

1987 Local Utilitarian Stonewares: A Diminishing Artifact Category. In Historic Buildings, Material Culture, and People of the Prairie Margin: Archirecture, Artifacts, and Synthesis of Historic Archaeology, edited by D. H. Jurney and R. W. Moir, pp. 121-142. Volume V. Archaeology Research Program, Institute for the Study of Earth and Man, Southern Methodist University, Dallas.

Leibowitz, J.

1985 Yellow Ware: The Transitional Ceramic. Schiffer Publishing Ltd., West Chester, Pennsylvania.

Majewski, T. and M. J. O’Brien

1987 The Use and Misuse of Nineteenth-Century English and American Ceramics in Archaeological Analysis. In Advances in Archaeological Method and Theory, Volume 11, edited by M. B. Schiffer, pp. 97-209. Academic Press, Inc., New York. 
Meissner, B. A.

1997 Making the Man: Remains of Clothing Recovered from the Alamodome Project. In Archaeology at the Alamodome: Investigations of a San Antonio Neighborhood in Transition, Volume III: Artifacts and Special Studies, edited by A. A. Fox, M. Renner, and R. J. Hard, pp. 119-164. Archaeological Survey Report No. 238. Center for Archaeological Research, The University of Texas at San Antonio.

Moir, R. W.

1987 Socioeconomic and Chronometric patterning of Window Glass. In Historic Buildings, Material Culture, and People of the Prairie Margin: Architecture, Artifacts, and Synthesis of Historic Archaeology, edited by D. H. Jurney and R. W. Moir, pp. 73-81. Volume V. Archaeology Research Program, Institute for the Study of Earth and Man, Southern Methodist University, Dallas.

Perttula, T. K.

2011 The Marcus Kolb Site (41CE438), Cherokee County, Texas. Journal of Northeast Texas Archaeology $34: 1-11$.

Wells, T.

2000 Nail Chronology: The Use of Technologically Derived Features. In Approaches to Material Culture Research for Historical Archaeologists, compiled by D. R. Brauner, pp. 318-339. $2^{\text {nd }}$ Edition. The Society for Historical Archaeology, California, Pennsylvania. 